\title{
Quantitative characterization of corn plant components according to planting time and grain maturity stage
}

\author{
José Luiz de Andrade Rezende Pereira ${ }^{1}$, Renzo Garcia Von Pinho ${ }^{1}$, Alano Xavier Souza \\ Filho $^{2}$, Marcos Neves Pereira ${ }^{2}$, Álvaro de Oliveira Santos ${ }^{2}$, Iran Dias Borges ${ }^{2}$
}

\author{
1 Universidade Federal de Lavras, Caixa Postal 37, 37200-000, Lavras - MG, Brasil. \\ 2 Universidade Federal de Lavras, Brasil.
}

\begin{abstract}
The objective of this experiment was to characterize the dry matter production of vegetative components (stalk, leaf, husk, and cob) and reproductive components (grain) of the corn plant according to planting time and the grain maturity stage. Eight corn hybrids with different agronomic characteristics were used to carry out the experiments. Two experiments were performed with planting undertaken on 11/11/2007 and 12/12/2007 under a conventional tillage system. The eight corn cultivars were harvested at three grain maturity stages, half milk line, three quarters milk line and black layer. An $8 \times 3$ factorial (eight hybrids and the three cutting times) randomized blocks design was used, with three replications. Individual analysis of variance was performed for each experiment. Then joint analysis of variance was performed involving the two planting times. The means were grouped and the hybrids used as replications to characterize the components. Delay in planting significantly reduced the dry matter productivity of the whole plant; however, it did not reduce its degradability. The greatest dry matter productivity obtained was that of grain, followed by stalk, leaf, husk and cob. The vegetative components, leaves and husk, lose quality with delay in planting. The leaf is the vegetative component of highest quality, while the cob is the worst. Delay in planting increases the neutral detergent fiber content of the stalk, husk and cob.
\end{abstract}

Key Words: digestibility, dry matter, fiber quality, forage, Zea mays

\section{Introduction}

Due to its high quality, corn silage is increasingly used in intensive beef and dairy livestock raising. The use of high quality silage may reduce the use of concentrates and feed cost, thus increasing profit for the producer.

There are various factors that can influence silage quality. Among them, those related to the agronomic and bromatological characteristics of the specific hybrids for silage production stand out (Mendes et al., 2008).

Until quite recently, it was thought that a greater share of grain in the dry matter of the forage would produce betterquality silage. However, some studies have shown that in addition to the grain, the vegetative components of the corn plant are also important in the improvement of forage quality (Campos Neto et al., 1997; Campos et al., 2001; Pereira etal., 2004; Mendes et al., 2008; and Silva et al., 2008).

The vegetative components (stalk, leaf, husk and cob) can constitute approximately $70 \%$ of the whole plant dry matter and can affect the quality of forage from the corn plant (Caetano, 2001).

This information shows the important role that the vegetative portion of the plant plays on the nutritional quality of corn silage. However, there are few studies that show the importance of each component of the plant in the in situ ruminal degradability of material to be silaged.

The choice of hybrids for silage production based exclusively on high dry matter and grain production must be reviewed, because qualitative variables such as digestibility of the dry matter (DM) and of neutral detergent fiber (NFD) must be considered (Manzano et al., 1999; Mendes et al., 2008).

Quantitatively characterizing and knowing the nutritional value of the fractions of the corn plant is extremely important for directing breeding programs so as to obtain more productive and specific hybrids for silage production.

Given the importance of the vegetative components in forage quality, the objective of this study was to quantitatively characterize the vegetative components (stalk, leaf, husk, cob) and reproductive components (grain) of corn hybrids harvested at three stages of maturity and from two different planting dates.

\section{Material and Methods}

Eight corn hybrids were used for the carrying out of the experiment. These hybrids were chosen because of their 
being recommended for silage production to producers in the region and for exhibiting different agronomic characteristics, such as genetic base, cycle, leaf architecture and grain texture (Table 1).

The study was carried out in the experimental area of the Agriculture Department of the Universidade Federal de Lavras (Universidade Federal de Lavras), located in the municipality of Lavras, Minas Gerais, Brazil, on a soil classified as Hapludox/ Dystroferric Red Latosol, of clayey texture and $9 \%$ slope. The municipality of Lavras is located at an altitude of $920 \mathrm{~m}$, at $21^{\circ} 14$ South latitude and $45^{\circ} 00 \mathrm{West}$ latitude. The climate in the region is of the dry winter temperate type $(\mathrm{Cwb})$. The annual average temperature is $19.3{ }^{\circ} \mathrm{C}$ and the annual average rainfall is $1,411 \mathrm{~mm}$.

During the period of the experiment, the area had average temperatures of $21.3,23.0,21.8,21.8$ and $21.9^{\circ} \mathrm{C}$ for the months of November/07, December/07, January/08, February/08 and March/08, respectively. Total rainfall throughout the experiment was $987 \mathrm{~mm}$.

Two experiments were performed with planting undertaken on $11 / 11 / 2007$ and $12 / 12 / 2007$, under the conventional tillage system.

The planting times recommended for the hybrids used in the experiments are October, November and December in the region of installation of the experiments.

For each planting time, the eight corn cultivars were harvested at three stages of grain maturity: at half milk line, at three quarters milk line and at black layer. For each experiment, an 8 (hybrids) $\times 3$ (cutting times) factorial randomized blocks design was used, with three replications. Each plot consisted of six rows of five-meter length, spaced at $80 \mathrm{~cm}$. The two center rows were considered the useful area of each plot for effects of data collection. Thinning was performed when the plants had two to three totally expanded leaves, for the purpose of obtaining a final stand of 60,000 plants/ha.

Fertilization at planting was $400 \mathrm{~kg} / \mathrm{ha}$ of the formula 08-28-16+0.5\% of Zn. Top-dress fertilization was performed

Table 1 - Characteristics of corn cultivars used in the experiments

\begin{tabular}{lcccc}
\hline Hybrid & Type $^{1}$ & Cycle $^{2}$ & Grain texture $^{3}$ & Use $^{4}$ \\
\hline AG1051 & DH & Me & Dent & G/WPS \\
AG4051 & TH & Me & Dent & G/WPS \\
AG5011 & TH & E & Dent & G/WPS \\
DOW2C577 & SH & E & SMDent & G \\
P30F90 & SH & E & H & G/WPS \\
NB7315 & SH & E & H & G \\
DOW2A525 & SH & E & SH & G \\
DOW2B710 & SH & E & SH & G
\end{tabular}

${ }^{1}$ Genetic base (SH - simple hybrid; TH - triple hybrid; DH - double hybrid).

${ }^{2} \mathrm{Me}$ - medium early; E - early.

${ }^{3} \mathrm{H}$ - hard; SMDent - semi dented; SH - semi hard; Dent - dented.

${ }^{4} \mathrm{G}$ - grain; WPS - whole plant silage. when the plants had five to six totally expanded leaves, using $350 \mathrm{~kg} / \mathrm{ha}$ of the formulation 30-00-20. For weed control, an Atrazine + Metalaclor based herbicide was used at pre-emergence, as well as an Atrazine application at a dose of 3 liters $\mathrm{ha}^{-1}$ at post emergence.

Plants of the two central rows of the plots were cut at $20 \mathrm{~cm}$ from the ground when the kernels of the ears of each hybrid were at the respective maturation stage of interest (half milk line, three quarters milk line and black layer). Fifteen plants from each plot were taken at random and were fractioned into stalk (C), leaf(F), husk (P), cob (S) and grain (G). Another fifteen plants from each plot were also taken at random and used to compose the whole plant sample (PI). The fractions were weighed for quantification of each component in the whole plant and then the whole plants and their fractions (except for the grain) were ground and homogenized for removal of samples. The grain samples were frozen before being subjected to ruminal degradation assessment.

A sample of the whole plant and of each plant component from each plot, of approximately $0.6 \mathrm{~kg}$, was dried in a forced ventilation laboratory oven at $55^{\circ} \mathrm{C}$ until reaching constant weight. After drying, the samples were ground in a knife mill, with a 5-mm sieve for carrying out the in situ degradation test of the dry matter. The kernels were cut in half while still frozen for assessment of the in situ degradation (Pereira et al., 2004).

The following characteristics were assessed in accordance with Souza Filho (2009): content of the whole plant dry matter and of the stalk, leaf, husk, cob and grain fractions, and also dry matter productivity of the whole plant and of the stalk, leaf, husk, cob and grain fractions and grain density.

For assessment of the in situ degradation, three cows with ruminal cannula were used, one Jersey breed, not milking and unbred, and two Holstein breed, milking and unbred. The daily diet of the animals was composed of $30 \mathrm{~kg}$ of corn silage, $3 \mathrm{~kg}$ of corn meal, $3 \mathrm{~kg}$ of soybean meal and mineral premix. The cows were adapted to this diet 20 days before the beginning of the assessments. Each cow received all the field plots of whole plant dry matter and dry matter of the fractions (stalk, leaf, husk, cob and grain).

The in situ degradability of the whole plant dry matter and dry matter of the fractions (stalk, leaf, husk, cob and grains) was determined according to the methodology described by Pereira et al. (2004). The in situ degradability of the whole plant dry matter and the dry matter of each fraction was determined by ruminal incubation at a time of 24 hours. Samples of $5 \mathrm{~g}$ per plot were incubated in "polyester" taffeta bags with dimensions of $9 \times 15 \mathrm{~cm}$, 
corresponding to a relationship of $18.5 \mathrm{mg} \mathrm{cm}^{-2}$, except for the kernels, which were cut into two parts, simulating silage processing, where eight grams of dry matter were inserted in the polyester bags. The small bags were placed within a tulle bag with the addition of weight to keep them immersed in the rumen. Before ruminal incubation, the bags were immersed in water at ambient temperature. After being removed from the rumen of the animals, the bags were immediately placed in cold water. The in situ degradation of the whole plant dry matter and dry matter of the fractions were calculated by the sum of the difference between the initial and final dry matter 24 hours after incubation in the three cows. The cows were simply considered replications so as to obtain the value of ruminal degradation by the following model:

$$
\mathrm{Y}_{\mathrm{jklm}=} \mu+\mathrm{b}_{\mathrm{j}}+\mathrm{c}_{\mathrm{k}}+\mathrm{p}_{1+\mathrm{v}_{\mathrm{m}}}+(\mathrm{cp})_{\mathrm{kl}}+\mathrm{e}_{\mathrm{jk} l}
$$

where: $\mu=$ general mean of the experiment; $b_{j}=$ effect of block $\mathrm{j}(\mathrm{j}=1,2,3, \ldots, 24) ; \mathrm{c}_{\mathrm{k}}=$ effect of the cutting time $\mathrm{k}$ $(\mathrm{k}=1,2,3) ; \mathrm{p}_{\mathrm{l}}=$ effect of the planting time $\mathrm{l}(\mathrm{l}=1,2) ; \mathrm{v}_{\mathrm{m}}=$ effect of cow $\mathrm{m}(\mathrm{m}=1,2,3)$; $(\mathrm{cp})_{\mathrm{kl}}$ : effect of interaction between the cutting time $\mathrm{k}$ and the planting time $1 ; \mathrm{e}_{\mathrm{jk} 1}=$ experimental error, with $\mathrm{e}_{\mathrm{jkl}} \cap \mathrm{N}\left(0, \sigma^{2}\right)$.

Neutral detergent fiber (NDF) and the degraded NDF were obtained through analysis in a fiber analyzer (Marconi brand, model MA-444) using neutral detergent solution as described by Van Soest et al. (1991). The bags used were made of unwoven fabric of $100 \mathrm{~g} / \mathrm{m}^{-2}$ grammage. The degraded NDF was calculated by the difference between the NDF of the original material and the NDF of the incubated material.

Individual analysis of variance was performed for each experiment. The ratio between the greatest and least error variance was less than seven for all the variables. Afterwards, joint analysis of variance was performed involving the two planting times. For analysis of quantitative characterization and of the bromatological characteristics of the corn plant components, the means generated (LSMEANS) were grouped and the hybrids were also used as replications for the characteristics assessed in the three cutting times and two planting times, totaling 24 replications. For degradability analyses, the cows were also considered replications.

The variables analyzed by this model met the presuppositions of analysis of variance and were performed by the GLM procedure of the $\mathrm{SAS}^{\circledR}$ (version 8).

\section{Results and Discussion}

Significant effect was observed for cutting time for all the variables analyzed $(P<0.01)$. Significance $(P<0.05)$ was observed for planting time only for the value of dry matter of the grains. The cutting time $\times$ planting time interaction was not significant $(\mathrm{P}<0.05)$ for any variables assessed (Table 2).

The mean values of the dry matter of the whole plant at half milk line, three quarters milk line and black layer were $334.0,412.8$ and $538.0 \mathrm{~g} / \mathrm{kg}$ of natural matter, respectively (Table 2). There was no interaction between cutting time and planting time (Table 2).

At the half milk line cutting time, the grain component was that which exhibited the greatest value of dry matter, followed by cob, husk, leaf and stalk (Table 2). At the three quarters milk line cutting time, for its part, the components that exhibited the greatest value of dry matter were grain, husk, cob and leaf (Table 2).

At black layer, the leaf component was that which had the greatest value of dry matter, followed by grain, husk, cob and stalk (Table 2).

Throughout the three cutting times, the leaf and husk components were those which exhibited the greatest increase in the value of dry matter, while the stalk and cob were those that exhibited the smallest increases (Table 2).

The leaves, along with the stalk, significantly contribute to the filling of kernels through translocation of photoassimilates (Bunting, 1976). In addition to senescence, rapid translocation of photoassimilates of the leaves and

Table 2 - Mean values ( $\mathrm{g} / \mathrm{kg}$ of natural matter) of the whole plant and of the components of eight corn hybrids planted in November and December and harvested at half milk line $(1 / 2 \mathrm{ML})$, three quarters milk line $(3 / 4 \mathrm{ML})$ and black layer $(\mathrm{BL})$

\begin{tabular}{|c|c|c|c|c|c|c|c|c|c|c|}
\hline & \multicolumn{3}{|c|}{ November } & \multicolumn{3}{|c|}{ December } & \multirow[t]{2}{*}{ SEM } & \multirow[t]{2}{*}{$\mathrm{EC}$} & \multirow[t]{2}{*}{ EP } & \multirow[t]{2}{*}{$\mathrm{EC} * \mathrm{EP}$} \\
\hline & $1 / 2 \mathrm{ML}$ & $3 / 4 \mathrm{ML}$ & $\mathrm{BL}$ & $1 / 2 \mathrm{ML}$ & $3 / 4 \mathrm{ML}$ & $\mathrm{BL}$ & & & & \\
\hline \multicolumn{11}{|c|}{$\mathrm{g} / \mathrm{kg}$ of natural matter } \\
\hline Stalk & 225.0 & 230.5 & 263.3 & 213.2 & 242.4 & 310.0 & 12.6 & $<0.01$ & 0.13 & 0.07 \\
\hline Leaf & 277.1 & 356.0 & 778.2 & 292.3 & 421.2 & 746.2 & 36.3 & $<0.01$ & 0.60 & 0.41 \\
\hline Husk & 336.0 & 443.0 & 687.3 & 338.2 & 524.4 & 672.3 & 25.3 & $<0.01$ & 0.28 & 0.15 \\
\hline
\end{tabular}


husk for the filling of kernels explains the water loss of these components with plant maturity (Dourado Neto \& Fancelli, 2004).

The cutting time significantly influenced the dry matter productivity of the leaf and grain components $(\mathrm{P}<0.01)$. Significance $(\mathrm{P}<0.05)$ was observed for productivity of the husk component. Productivity of the dry matter of the other components was not influenced by the cutting time (Table 3 ).

Planting time influenced the dry matter productivity $(\mathrm{P}<0.01)$ of all the components, except for the cob, which did not undergo any influence from the planting time (Table 3 ).

The cutting time $\times$ planting time interaction was significant $(\mathrm{P}<0.01)$ only for dry matter productivity of the whole plant. This result means that productivity of the components was similar in the same cutting time, considering the two planting dates (Table 3).

In the experiment started in November, mean productivity of the whole plant dry matter was $21,856,24,103$ and $23,865 \mathrm{~kg} / \mathrm{ha}$ at half milk line, three quarters milk line and black layer, respectively. The mean of this variable in the experiments installed in November was $23,271 \mathrm{~kg} / \mathrm{ha}$ while, in December, whole plant dry matter productivity was $18,100,18,875$ and $20,200 \mathrm{~kg} / \mathrm{ha}$. The mean for the experiments planted in December was $19,058 \mathrm{~kg} / \mathrm{ha}$. With the delay in planting, there was reduction in whole plant dry matter productivity of $4,213 \mathrm{~kg} / \mathrm{ha}$; in other words, $18.1 \%$ (Table 3 ). Gomes et al. (2004b), in addition to reduction in whole plant dry matter productivity, also observed losses in forage quality with delay in planting.

Cutting time and planting time significantly influenced leaf, husk and grain productivity. Dry matter productivity of the cob was influenced only by the planting time (Table 3).

Mean productivity of stalk dry matter was not influenced by cutting time or planting time. In this study, the mean productivity of stalk dry matter was $4607 \mathrm{~kg} / \mathrm{ha}$ (Table 3 ).

The stalk, in addition to its structural function in the plant, is a reserve tissue and contributes to the supply of photoassimilates for grain filling. Environmental factors (defoliation, cloudiness, water deficit, etc.) directly influence the source-drain relationship, increasing the stalk contribution in supply of photoassimilates to the grain (Borges, 2006).

Carter et al. (1994) cite diverse studies with negative correlation coefficients between grain production and production of vegetative components; this loss of the vegetative fraction of the dry matter is an event concomitant with loss in the quality of these components.

Borges (2006), evaluating the dry matter and nutrient accumulation in different parts of the plant, found stalk productivities of $5360 \mathrm{~kg} / \mathrm{ha}, 6962 \mathrm{~kg} / \mathrm{ha}$ and $6606 \mathrm{~kg} / \mathrm{ha}$ in the phenological stages E8, E9 and E10 representing $22.5 \%, 22.7 \%$ and $21.2 \%$ share of this fraction in total dry matter, respectively. These values are similar to those found in this study.

Productivity of the leaf component was influenced $(\mathrm{P}<0.01)$ by the factors of cutting time and planting time (Table 3). The greatest leaf productivity was obtained in the half milk line cutting time $(4139.5 \mathrm{~kg} / \mathrm{ha})$, while the smallest was obtained at the black layer cutting time $(3498.0 \mathrm{~kg} / \mathrm{ha})$ (Table 3). Decrease in leaf productivity throughout the stages of maturity may affect forage quality (Souza Filho, 2009). The experiment installed in December simulating delay in planting had less productivity of leaf dry matter $(3561.7 \mathrm{~kg} / \mathrm{ha})$ while, in November, leaf productivity was $4189 \mathrm{~kg} / \mathrm{ha}$ (Table 3). The leaf is the vegetative component of highest quality; therefore, delay in planting reduces forage quality because it reduces the productivity of this component (Souza filho, 2009).

Husk dry matter productivity in the experiments installed in November was $2421 \mathrm{~kg} / \mathrm{ha}, 2037 \mathrm{~kg} / \mathrm{ha}$ and $2059 \mathrm{~kg} / \mathrm{ha}$ for the cutting time performed at half milk line, three quarters milk line and black layer, whereas for the experiments installed in December, the productivities were $1727 \mathrm{~kg} / \mathrm{ha}$, $1713 \mathrm{~kg} / \mathrm{ha}$ and $1476 \mathrm{~kg} / \mathrm{ha}$. The means of husk dry matter

Table 3 - Mean productivity ( $\mathrm{kg} / \mathrm{ha}$ ) of dry matter of the whole plant and of the components of eight corn hybrids planted in November and December, harvested at half milk line $(1 / 2 \mathrm{ML})$, three quarters milk line $(3 / 4 \mathrm{ML})$ and black layer (BL)

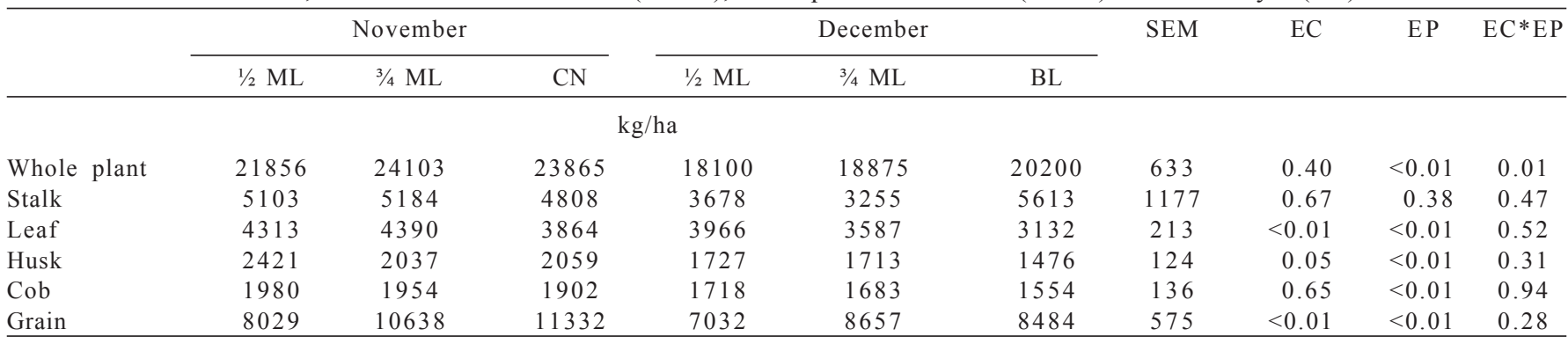

SEM - standard error of the mean; EC - probability of significance (P) for cutting time effect; EP - P for planting time effect; EC*EP - P for interaction between cutting time and planting time ratio. 
productivity were $2074 \mathrm{~kg} / \mathrm{ha}, 1875 \mathrm{~kg} / \mathrm{ha}$ and $1776 \mathrm{~kg} / \mathrm{ha}$ for the cutting times half milk line, three quarters milk line and black layer, respectively (Table 3 ).

Productivity of the cob component was affected only by planting time. In November, cob dry matter productivity was $1945 \mathrm{~kg} / \mathrm{ha}$, while in the experiments installed in December, productivity was $1651 \mathrm{~kg} / \mathrm{ha}$ (Table 3 ).

The cutting time and planting time factors significantly affected grain dry matter productivity. In November, mean productivities of grain dry matter was $8,029 \mathrm{~kg} / \mathrm{ha}, 10,638 \mathrm{~kg} / \mathrm{ha}$ and $11,332 \mathrm{~kg} \mathrm{ha}^{-1}$ for the cutting times half milk line, three quarters milk line and black layer respectively. For the plantings performed in December, for their part, the grain dry matter productivities were $7,032 \mathrm{~kg} / \mathrm{ha}^{-1}, 8,657 \mathrm{~kg} / \mathrm{ha}^{-1}$ and $8,484 \mathrm{~kg} /$ ha for the cutting times at half milk line, three quarters milk line and black layer (Table 3). The grain component was that which had the greatest dry matter productivity, followed by stalk, leaf, husk and cob (Table 3).

One of the best ways of assessing silage quality of a corn cultivar is by means of forage dry matter degradability (Oliveira, 1997). Gomes et al. (2004a), Mendes et al. (2008) observed a high correlation between the 24-hour incubation period and the effective degradability, indicating the possibility of assessing dry matter degradability in the 24hour incubation period. The cutting time significantly $(\mathrm{P}<0.01)$ affected the dry matter degradability of all the components assessed in the 24-hour incubation period. Only the leaf, husk and grain components underwent significant $(\mathrm{P}<0.01)$ influence of probability from the planting time (Table 4).

The mean values of the whole plant dry matter degradability were $54.1 ; 53.05$; and $49.95 \mathrm{~g} / 100 \mathrm{~g}$ of dry matter for the cutting times half milk line, three quarters milk line and black layer (Table 4). Contrary to the results of Gomes et al. (2004a), delay in planting in this experiment did not lead to loss of quality in whole plant dry matter. With the advance of physiological maturity of the plant, there was reduction in the vegetative fraction share of 10.2 percentage units, while the grain share had an increase of 10.3 percentage units.

These results show the importance of the quality of the vegetative fraction in the choice of a hybrid for silage production. With advance in the cutting time, loss of whole plant fiber quality is significant, and this is an important factor for reduction in whole plant dry matter degradability (Tables 4 and 5).

The degradability of the dry matter of the stalk component was greater in the half milk line cutting time, followed by the three quarters milk line and black layer, whose values were $37.7,36.3$, and $30.55 \mathrm{~g} / 100 \mathrm{~g}$ of dry matter (Table 4 ). The stalk was the component that lost least quality from the half milk line to black layer cuttings times, around 7.15 percentage units. The components that most lost quality were grains, leaves, husk and cob, exhibiting the values $14.75,11.5$, 11.05 and 10.2 percentage units, respectively.

The stalk is the vegetative component with the greatest share in the whole plant dry matter (Table 3). Several authors (Casler \& Jung, 2006; Cepon et al., 1995; Correa et al., 2002) found variability in the digestibility of this component. Beleze et al. (2003) highlighted the importance of using corn hybrids with good digestibility of the stalk fraction, allowing savings in feed concentrate. Therefore, more detailed studies on the quality of this component will lead to the use of more specific hybrids for silage production.

The leaf component was that which exhibited the greatest dry matter degradability (Table 4 ).

The degradability of the dry matter of the husk component reduced with the advance of cutting times in the experiment performed in December, simulating delay in planting (Table 4).

Table 4 - Mean degradability (g/100 g) of dry matter in $24 \mathrm{~h}$ of the whole plant, of the components, and grain density of eight corn hybrids planted in November and December and harvested in half milk line ( $1 / 2 \mathrm{ML})$, three quarters milk line ( $3 / 4 \mathrm{ML})$ and black layer (BL)

\begin{tabular}{|c|c|c|c|c|c|c|c|c|c|c|}
\hline & \multicolumn{3}{|c|}{ November } & \multicolumn{3}{|c|}{ December } & \multirow[t]{2}{*}{ SEM } & \multirow[t]{2}{*}{ EC } & \multirow[t]{2}{*}{ EP } & \multirow[t]{2}{*}{$\mathrm{EC} * \mathrm{EP}$} \\
\hline & $1 / 2 \mathrm{ML}$ & $3 / 4 \mathrm{ML}$ & $\mathrm{BL}$ & $1 / 2 \mathrm{ML}$ & $3 / 4 \mathrm{ML}$ & BL & & & & \\
\hline \multicolumn{11}{|c|}{$\mathrm{g} / 100 \mathrm{~g}$ of dry matter } \\
\hline Whole plant & 54.6 & 53.4 & 49.6 & 53.6 & 52.7 & 50.3 & 0.73 & $<0.01$ & 0.56 & 0.46 \\
\hline Stalk & 38.8 & 38.3 & 31.9 & 36.6 & 34.3 & 29.2 & 2.40 & $<0.01$ & 0.13 & 0.93 \\
\hline Leaf & 50.4 & 40.9 & 36.6 & 44.5 & 38.3 & 35.3 & 1.13 & $<0.01$ & $<0.01$ & 0.12 \\
\hline Husk & 44.6 & 35.7 & 30.9 & 38.3 & 30.0 & 29.9 & 1.28 & $<0.01$ & $<0.01$ & 0.09 \\
\hline Cob & 28.8 & 27.5 & 24.9 & 35.7 & 26.4 & 19.2 & 1.43 & $<0.01$ & 0.95 & $<0.01$ \\
\hline Grain & 32.9 & 21.0 & 18.1 & 34.6 & 24.0 & 19.9 & 0.74 & $<0.01$ & $<0.01$ & 0.62 \\
\hline \multicolumn{11}{|c|}{ g. $\mathrm{cm}^{3}$} \\
\hline Density & 1.08 & 1.11 & 1.13 & 1.12 & 1.14 & 1.15 & 0.01 & $<0.01$ & 0.02 & 0.84 \\
\hline
\end{tabular}

SEM - standard error of the mean; EC - probability of significance (P) for cutting time effect; EP - P for planting time effect; EC*EP - P for interaction between cutting time and planting time ratio. 
The cob was the component that exhibited least degradability (Table 4). Nevertheless, at the half milk line, the degradability of this component was greater than in the other cutting times (Table 4).

Degradability of the grain was that which most decreased with advance in the cutting time; specifically, $14.8 \%$, considering the two planting times (Table 4 ). The means were $32.9,21.0$, and $18.1 \mathrm{~g} / 100 \mathrm{~g}$ of dry matter for the half milk line, three quarters milk line and black layer cutting times in the experiments performed in November. In the experiments of December, the means were 35.7, 26.4, and $19.2 \mathrm{~g} / 100 \mathrm{~g}$ of dry matter for the cutting times at half milk line, three quarters milk line and black layer (Table 4). Correa (2002) reports that grain degradability has a high positive correlation with its density. In this study, the same behavior observed for grain degradability was observed for density; in other words, advance of maturity and delay in planting reduce quality and increase the density of this component (Table 4).

Bal et al. (1997) found reduction of approximately $5 \%$ in grain degradability from the three quarters milk line to black layer stage. Pereira et al. (2004), for their part, found reduction in $24 \mathrm{~h}$ degradability of grain of $74 \%$ for hard texture hybrids and $51 \%$ for materials of dented texture throughout the initial dented stage and black layer.

Various factors may affect grain degradability (Allen et al., 2003). Among them, particle size, grain vitreousness (Ngonyamo-Majee et al., 2008), more advanced stages of maturity (Champion \& Ramos, 2009), diets with high starch concentration and changes in the ruminal environment may be highlighted (Edwards et al., 1995).
Fonseca (2000) observed that among all the characteristics that determine forage quality, the NDF content was the variable most correlated with dry matter digestibility.

Shaver (2006) highlighted evolution in forage assessments that were based exclusively on fiber contents (ADF and NDF) and came to be based also on digestibility of fibers, proteins, fatty acids, non-fibrous carbohydrates and starch.

In this study, the cutting time significantly affected the neutral detergent fiber (NDF) of the whole plant and of the components: stalk, leaf, husk and cob at $(\mathrm{P}<0.01)$, except for the NDF content of the stalk, which was significant $(\mathrm{P} \leq 0.05)$. The planting time, for its part, only affected the stalk NDF contents ( $\mathrm{P} \leq 4 \%)$, the husk NDF, and cob ( $\mathrm{P} \leq 0.01)$ (Table 5).

The means of whole plant neutral detergent fiber contents were $492.0 ; 450.0$ and $447.0 \mathrm{~g} / \mathrm{kg}$ at the half milk line, three quarters milk line and black layer cutting times, respectively. Various studies have shown that the NDF values decrease with the advance in maturity and explain that this reduction occurs due to the dilution effect through starch accumulation with the advance in plant maturity (Aello et al., 2002; Filya, 2004).

For the stalk, the means of neutral detergent fiber contents were 740,$0 ; 739,0$ and $789.0 \mathrm{~g} / \mathrm{kg}$ for the half milk line, three quarters milk line and black layer cutting times (Table 5). For the experiments performed in November, the mean of the NDF for the stalk component was $736.0 \mathrm{~g} / \mathrm{kg}$, while for the experiment of December, the mean was $775.5 \mathrm{~g} / \mathrm{kg}$ (Table 5). Masoero et al. (2006) observed an increase of NDF in the stalk in the R4 to R6 stages, with a

Table 5 - Mean values (g/kg of dry matter) of neutral detergent fiber (NDF) and degraded NDF in $24 \mathrm{~h}$ of the whole plant and of the components of eight corn hybrids planted in November and December and harvested at half milk line ( $1 / 2 \mathrm{ML})$, three quarters milk line $(3 / 4 \mathrm{ML})$ and black layer $(\mathrm{BL})$

\begin{tabular}{|c|c|c|c|c|c|c|c|c|c|c|}
\hline & \multicolumn{3}{|c|}{ November } & \multicolumn{3}{|c|}{ December } & \multirow[t]{2}{*}{ SEM } & \multirow[t]{2}{*}{$\mathrm{EC}$} & \multirow[t]{2}{*}{ EP } & \multirow[t]{2}{*}{$\mathrm{EC} * \mathrm{EP}$} \\
\hline & $1 / 2 \mathrm{ML}$ & $3 / 4 \mathrm{ML}$ & BL & $1 / 2 \mathrm{ML}$ & $3 / 4 \mathrm{ML}$ & BL & & & & \\
\hline \multicolumn{11}{|c|}{$\mathrm{g} / 100 \mathrm{~g}$ of dry matter } \\
\hline Stalk & 732.0 & 722.0 & 755.2 & 748.5 & 756.2 & 822.2 & 22.3 & 0.05 & 0.04 & 0.51 \\
\hline Leak & 732.0 & 752.0 & 808.3 & 747.3 & 769.1 & 801.4 & 11.8 & $<0.01$ & 0.39 & 0.54 \\
\hline Husk & 802.0 & 851.0 & 866.4 & 836.6 & 897.5 & 933.2 & 13.6 & $<0.01$ & $<0.01$ & 0.49 \\
\hline Whole plant & 288.0 & 251.0 & 229.4 & 272.2 & 241.0 & 240.6 & 7.9 & $<0.01$ & 0.44 & 0.21 \\
\hline Stalk & 214.2 & 207.4 & 163.3 & 202.6 & 186.2 & 198.7 & 12.9 & 0.12 & 0.97 & 0.07 \\
\hline Leak & 399.3 & 312.2 & 310.4 & 318.3 & 300.2 & 292.1 & 10.7 & $<0.01$ & $<0.01$ & $<0.01$ \\
\hline Husk & 336.3 & 281.7 & 255.2 & 300.2 & 263.2 & 279.8 & 12.1 & $<0.01$ & 0.33 & 0.05 \\
\hline Cob & 178.2 & 199.3 & 195.2 & 274.0 & 197.1 & 173.1 & 14.2 & 0.02 & 0.05 & $<0.01$ \\
\hline
\end{tabular}

SEM - standard error of the mean; EC - probability of significance $(\mathrm{P})$ for cutting time effect; EP - P for planting time effect; EC*EP - P for interaction between cutting time and planting time ratio. 
decrease in the in vitro degradability of the stalk fraction also observed. Estrada-Flores et al. (2006) also observed the same behavior.

The means for the leaf component were $739.5 ; 760.5$ and $805.0 \mathrm{~g} / \mathrm{kg}$ in the cutting at half milk line, three quarters milk line and black layer, respectively (Table 5).

The NDF contents of the husk were 819.0, 874.0, and $899.5 \mathrm{~g} / \mathrm{kg}$ at half milk line, three quarters milk line and black layer (Table 5).

The NDF of the cob was $815.0,843.0$, and $882.0 \mathrm{~g} / \mathrm{kg}$ of dry matter at half milk line, three quarters milk line and black layer cutting times (Table 5). Among the components assessed, the cob was that which exhibited the greatest values of NDF, followed by husk, leaf and stalk (Table 5).

Degraded NDF is, without a doubt, an important parameter in assessment of forage quality. Mertens et al. (1991) considered that degradability of the cell wall components is the greatest limitation for animal performance; and this characteristic is the most promising at indication of the nutritional value for selection of high-quality cultivars.

Assessing qualitative parameters of corn silages, Mello et al. (2005) found greater values for dry matter in vivo degradability for the hybrids with the greatest degradable NDF contents. Furthermore, various studies show that in a single fiber content, there are differences in the degradable NDF, which is able to lead to an increase in ingestion of dry matter and in milk production (Allen, 1996; Schwab et al., 2003). However, good sense should prevail in this matter, because results of greater degradabilities and degraded NDF contents are not always followed by improvement in the performance of dairy cows (Kuehn et al., 1997; Nennich et al., 2003).

In this study, there was reduction in the quality of the fiber throughout the cutting times, except for the stalk component (Table 5).

Aello et al. (2002) found reduction of up to $50 \%$ in NDF degradability from the flowering stage up to half milk line. Decrease in degraded NDF was also observed by Browne et al. (2005) and Estrada-Flores et al. (2006).

Among the components assessed, the leaf fraction exhibited the greatest degraded NDF values; these results are in agreement with those found by Gan et al. (2008); Sundstùlc \& Toleraa (1999). The senescence process reduced the degraded NDF and increased the NDF content by the remobilization of photoassimilates for the grain. Similar behavior was also observed by other authors (Herrmann et al, 2008; Hunt et al., 1998; Masoero et al., 2006).

Among the components studied, the cob was that which exhibited the lowest values of degraded NDF. The means for the degraded NDF values for the experiments started in November were 178.2, 199.3, and $195.2 \mathrm{~g} / \mathrm{kg}$ in the cutting times performed at half milk line, three quarters milk line and black layer, respectively, while for the experiment performed in December, the means were 274.0, 197.1, and $173.1 \mathrm{~g} / \mathrm{kg}$ (Table 5). Due to the low values of degradability and of the degraded NDF, the cob is the component which has the worst quality in composition of the plant. Thus, the choice of hybrids that produce little cob and with a low NDF value is interesting for improvement of forage quality.

\section{Conclusions}

Delay in planting reduces whole plant dry matter productivity; however, it does not reduce its degradability. The greatest dry matter productivity obtained was of grain, followed by stalk, leaf, husk and cob. The leaf, husk and grain components lose quality with delay in planting. The leaf is the vegetative component of highest quality, while the cob is the worst. Planting delay increases the neutral detergent fiber of stalk, husk and cob.

\section{References}

AELLO, M.S.; DI MARCO, O.N.; NOMDEDEU, M. Effect of maize crop maturity on silage chemical composition and digestibility (in vivo, in situ and in vitro). Animal Feed Science and Technology, v.99, p.37-43, 2002.

ALLEN, M.S. Physical constraints on voluntary intake of forages by ruminants. Journal of Animal Science, v.74, p.3063-75, 1996.

ALlEN, M.S.; COORS, J.G.; ROTH, G.W. Corn silage. In BUXTON, D.R.; MUCK, R.E.; HARRISON, J.H. (Eds.). Silage science and technology. Madison: ASA, 2003. p.547-608.

BAL, M.A.; COORS, J.G.; SHAVER, R.D. Impact of maturity of corn for use as silage in the diets of dairy cows on intake, digestion, and milk production Journal of Dairy Science, v.80, p.2497-2503, 1997.

BORGES, I.D. Marcha de absorção de nutrientes e acúmulo de matéria seca em milho. 2006. 115f. Tese (Doutorado em Fitotecnia) - Universidade Federal de Lavras, Lavras.

BELEZE, J.R.F.; ZEOULA, L.M.; CECATO, U. et al. Avaliação de cinco híbridos de milho (Zea mays, L.) em diferentes estádios de maturação. 1. Produtividade, características morfológicas e correlações. Revista Brasileira de Zootecnia, v.32, n.3, p.529-537, 2003

BROWNE, E.M.; JUNIPER, D.T.; BRYANT, M.J. et al. Apparent digestibility and nitrogen utilization of diets based on maize silage harvested at three stages of maturity and fed to steers. Grass and Forage Science, v.60, n.3, p.274-282, 2005.

BUNTING, E.S. Effect of grain formation on dry matter distribution and forage quality in maize. Experimental Agriculture, v.12, p. 417-428,1976.

CAETANO, H. Avaliação de onze cultivares de milho colhidos em duas alturas de corte para produção de silagem. 2001. 178f. Tese (Doutorado em Fitotecnia) - Faculdade de Ciências Agrárias e Veterinárias/Universidade Estadual Paulista "Júlio de Mesquita Filho", Jaboticabal.

CAMPOS, F.P.; DIAS, F.N.; NUSSIO, L.G. Importância da qualidade da porção vegetativa no valor alimentício da silagem de milho. 
In: SIMPÓSIO SOBRE PRODUÇÃO E UTILIZAÇÃO DE FORRAGENS CONSERVADAS, 2001, Maringá. Anais... Maringá: UEM, 2001. v.1, p.127-145.

CAMPOS NETO, O.; LAVEZZO, O.E.N.M.; LAVEZZO, W. Estádio de desenvolvimento do milho. Efeito sobre produção, composição da planta e qualidade da silagem. Revista Brasileira de Zootecnia, v.26, n.4, p.675-682, 1997.

CARTER, P.R.; COORS, J.G.; HUNTER, R.B. Silage corn. In: HALLAUER, A.R. (Ed.). Specialty corns. Boca Raton: CRC, 1994. p.305-340.

CASLER, M.D.; JUNG, H.G. Maize stem tissues: impact of development on cell wall degradability. Crop Science, v.46, n.1, p.1801-1809, 2006.

CEPON, M.R.; STEKAR, J.M.A.; VERBIC, J. Rumen degradation characteristics and fibre composition of various morphological parts of different maize hybrids and possible consequences for breeding. Animal Feed Science and Technology, v.54, n.1, p.133-148, 1995.

CHAMPION, M.C.P.; RAMOS, B.M.O. Effects of vitreousness and particle size of maize grain on ruminal and intestinal in sacco degradation of dry matter, starch and nitrogen. Animal Feed Science and Technology, v.148, p.253-266, 2009.

CORREA, C.E.S.; SHAVER, R.D.; PEREIRA, M.N. et al. Relation between corn vitreoness and ruminal in-situ starch degradability. Jounal of Dairy Science, v.85, n.11, p.3008-3010, 2002.

DOURADO NETO, D.; FANCELLI, A.L. Ecofisiologia e fenologia. In:____ Produção de milho. 4.ed. Guaíba: Agropecuária, 2004. p.31-54

EDWARDS, R.A.; GREENHALGH, J.F.D.; McDONALD, P. Animal Nutrition. 4.ed. Essex: Longman Scientific \& Technical, 1995. $543 p$.

ESTRADA-FLORES, J.G.; GONZÁLEZ-RONQUILLO, M.; MOULD, F.L. et al. Chemical composition and fermentation characteristics of grain and different parts of the stover from maize land races harvested at different growing periods in two zones of central Mexico. Animal Science, v.82, n.6, p.845-852, 2006.

FILYA, I. Nutritive value and aerobic stability of whole crop maize silage harvested at four stages of maturity. Animal Feed Science and Technology, v.116, n.1, p.141-150, 2004

FONSECA, A.H. Características químicas e agronômicas associadas à degradabilidade da silagem de milho. 2000. 93f. Dissertação (Mestrado em Fitotecnia) - Universidade Federal de Lavras, Lavras.

GAN, J.; TANG, S.X.; SHENG, L.X. et al. Morphological fractions, chemical composition and in vitro fermentation characteristics of maize stover of five genotypes. Animal, v.2, n.12, p.772-1779, 2008.

GOMES, M.S.; VON PINHO, R.G.; RAMALHO, M.A.P. et al. Análise dialélica da degradabilidade in situ da matéria seca da silagem de milho. Revista Brasileira de Milho e Sorgo, v.3, n.1, p.108-119, 2004a.

GOMES, M.S.; VON PINHO, R.G.; RAMALHO, M.A.P. et al. Variabilidade genética em linhagens de milho nas características relacionadas com a produtividade de silagem. Pesquisa Agropecuária Brasileira, v.39, n.9, p.879-885, 2004b.

HERRMANN, A.; KORNHER, A.; KRUSE, S. Evaluation of genotype and environmental variation in fibre content of silage maize using a model-assisted approach. European Journal Agronomy, v.28, n.1, p.210-223, 2008

HUNT, C.W.; KEZAR, W.; VINANDE, R. Yield, chemical composition, and ruminal fermentability of corn whole plant, ear, and stover as affected by maturity. Journal of Production Agriculture, v.2, p.357-361, 1998.

KUEHN,C.S.; LINN, J.G.; JOHNSON, D.E. et al. Effect of feeding corn hybrids selected for leafiness or grain to lactating dairy cattle. Madison: Dairy Forage Research Center, 1997. 220p.

MANZANO, R.P.; NUSSIO, L.G. Silagem de milho. In: SIMPÓSIO SOBRE NUTRIÇÃO DE BOVINOS, 7., 1999, Piracicaba. Anais... Piracicaba: FEALQ, 1999. p.27-46.

MASOERO, F.; PULIMENO, A.M.; ROSSI, F. Chemical composition and in vitro digestibility of stalks, leaves and cobs of four corn hybrids at different phonological stages. Italian Journal of Animal Science, v.5, n.1, p.215-227, 2006.

MELLO, R.; NÖRNBERG, J.L.; ROCHA, M.G. et al. Características produtivas e qualitativas de híbridos de milho para produção de silagem. Revista Brasileira de Milho e Sorgo, v.4, n.1, p.79-94, 2005.

MENDES, M.C.; PEREIRA, M.N.; VON PINHO, R.G. Avaliação de híbridos de milho obtidos do cruzamento entre linhagens com diferentes níveis de degradabilidade da matéria seca. Bragantia, v. 67, n.2, p.285-297, 2008 .

MERTENS, D.R.; SATTER, L.D.; WATTIAUX, M.A. Effect of source and amount of fiber on kinetics of digestion and specific gravity of forage particles in the rumen. Journal of Dairy Science, v.74, p.3872-83, 1991.

NENNICH, T.D.; LINN, J.G.; JOHNSON, D.G. Comparison of feeding corn silages from feafy or conventinonal corn hybrids to lactatinh dairy cow. Journal of Dairy Science, v.86, n.9, p.2932-2939, 2003

NGONYAMO-MAJEE, D.; SHAVER, R.D.; COORS, J.G. et al. Relationships between kernel vitreousness and dry matter degradability for diverse corn germplasm II. Ruminal and postruminal degradabilities. Animal Feed Science and Technology, v.142, p.259-274, 2008.

OLIVEIRA, J.S. Avaliação da qualidade da planta de milho para silagem. In: REUNIÃO ANUAL DA SOCIEDADE BRASILEIRA DE ZOOTECNIA, 34., 1997, Juiz de Fora. Anais... Juiz de Fora: SBZ, 1997. v.1, p.161-163.

PEREIRA, M.N.; VON PINHO, R.G; BRUNO, R.G.S. et al. Ruminal degradability of hard or soft texture corn grain at three maturity stages. Scientia Agricola, v.61, n.4, p.358-363, 2004.

SCHWAB, E.C.; SHAVER, R.D.; LAUER, J.G. et al. Estimating silage energy value and milk yield to rank corn hybrids. Animal Feed Science and Technology, v.109, n.1, p.1-18, 2003.

SHAVER, R.D. [2006] Corn silage evaluation: MILK2000 challenges and opportunities with MILK2006. Available at: $<$ http://www.wisc.edu/dysci/uwex/nutritn/pubs/milk2006 weblinktext.pdf>. Accessed on: Dec. 15, 2009.

SILVA, L.F.P.; CASSOLI, L.D.; ROMA JÚNIOR, L.C. et al. In situ degradability of corn stover and elephant-grass harvested at four stages of maturity. Scientia Agricola, v.65, n.6, p.595-603, 2008.

SOUZA FILHO, A.X. Avaliação de componentes da planta e da forragem de híbridos de milho colhidos em diferentes estádios fenológicos. 2009. 84f. Dissertação (Mestrado em Fitotecnia) - Universidade Federal de Lavras, Lavras.

SUNDSTÚLC, F.; TOLERAA, A. Morphological fractions of maize stover harvested at different stages of grain maturity and nutritive value of different fractions of the stover. Animal Feed Science and Technology, v.81, n.1-2, p.1-16, 1999.

VAN SOEST, P.J.; ROBERTSON, J.B.; LEWIS, B.A. Methods for dietary fiber, neutral detergent fiber and nonstarch polysaccharides in relation to animal nutrition. Journal of Dairy Science, v.74, p.3583-3597, 1991 . 